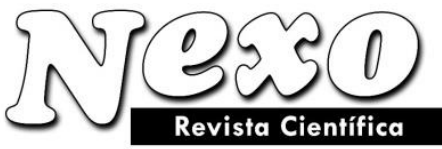

Vol. 34, No. 02, pp. 848-858/Junio 2021
ISSN-E 1995-9516

Universidad Nacional de Ingeniería COPYRIGHT (C) (UNI). TODOS LOS DERECHOS RESERVADOS http://revistas.uni.edu.ni/index.php/Nexo https://doi.org/10.5377/nexo.v34i02.11593

\title{
Detecting the potential lead, zinc, and gold orebodies by integrating remote sensing, geochemical, and geophysical studies in Dehshir (Iran)
}

\section{Detección de los posibles cuerpos minerales de plomo, zinc y oro mediante la integración de estudios de teledetección, geoquímicos y geofísicos en Dehshir (Irán)}

\author{
Faezeh Ahmadi ${ }^{1}$, Mohammad Reza Jafari ${ }^{1}$, Ahmad Adib*2 ${ }^{2}$, Hamid Hrati ${ }^{3}$, Mohammad Ali \\ Arian $^{1}$ \\ ${ }^{1}$ Department of Geology, North Tehran Branch, Islamic Azad University, Tehran, Iran. \\ ${ }^{2}$ Department of Petroleum Engineering, South Tehran Branch, Islamic Azad University, \\ Tehran, Iran. \\ ${ }^{3}$ Department of Geology, Payame Noor University, Tehran, Iran. \\ *adib@azad.ac.ir
}

(recibido/received: 28-octubre-2020; aceptado/accepted: 15-enero-2021)

\begin{abstract}
Nowadays, exploration management, increasing productivity, and reducing exploration costs are among the most important issues in the detailed exploration stage of orebodies. A geographic information system (GIS) is an effective tool for gathering, storing, analyzing, updating, generating, integrating, and displaying geographic data and land reference. ArcGIS is one of the efficient and powerful GIS computer programs with numerous capabilities such as generating databases, managing the data and information, integrating the information, and generating different outputs in the form of various maps, charts, and tables. In this study, different exploratory layers with different types of information from the Dehshir orebody area were integrated into this software to determine the spread of metal and introduce the parts with higher anomalies for subsurface exploration. For this purpose, we used the information from remote sensing, topography, geomorphology, geology, and geophysics, and geochemistry studies in the form of exploratory layers.
\end{abstract}

Keywords: Orebody; Remote sensing; Geochemistry; Dehshir; Iran

\section{RESUMEN}

Hoy en día, la gestión de la exploración, el aumento de la productividad y la reducción de los costos de exploración se encuentran entre los temas más importantes en la etapa de exploración detallada de los 
yacimientos. Un sistema de información geográfica (SIG) es una herramienta eficaz para recopilar, almacenar, analizar, actualizar, generar, integrar y mostrar datos geográficos y referencias territoriales. ArcGIS es uno de los programas informáticos SIG eficientes y potentes con numerosas capacidades, como generar bases de datos, administrar los datos y la información, integrar la información y generar diferentes resultados en forma de varios mapas, gráficos y tablas. En este estudio, se integraron en este software diferentes capas exploratorias con diferentes tipos de información del área del yacimiento de Dehshir para determinar la dispersión del metal e introducir las partes con mayores anomalías para la exploración del subsuelo. Para ello, utilizamos la información de los estudios de teledetección, topografía, geomorfología, geología y geofísica y geoquímica en forma de capas exploratorias.

Palabras clave: Cuerpo mineral; Sensores remotos; Geoquímica; Dehshir; Irán.

\section{INTRODUCCIÓN}

Satellite image processing methods are generally classified into two groups of basic statistics and base spectrum. In basic statistics methods, processing principles are defined based on the distribution of the histogram of each band pixel values as the mean, mode, and middle of the data. Although in base spectrum methods, a specific reference spectral pattern should be available from the beginning of processing, spectral information is still required in interpreting the resulting data as in basic statistical methods. However, the processing method is based only on the statistical principles of image bands. In base spectrum methods, the reference spectrum pattern must be specified in advance. Hyperspectral data include a rich set of information on the surface electromagnetic reflections. Objects reflect or absorb electromagnetic waves at different wavelengths with various intensities depending on their physical properties as well as mineralogical and chemical compositions. Thus, information on the spectral behavior of objects at different wavelengths is very important in remote sensing in terms of the reflection and absorption index curves of the spectrum (Gupta, 2003). Through hyperspectral sensors, accurate spectroscopy of the earth's surface is provided by imaging at subtle wavelengths. Hyperion sensor is one of the most advanced hyperspectral sensors on the EO-1 satellite platform. The Hyperion images are captured in 242 bands at wavelengths of 356-2577 $\mathrm{nm}$. Only 198 bands of the 242 bands imaged by the sensor are calibrated and can be used in image processing operations. The spatial resolution of the Hyperion sensor is $30 \mathrm{~m}$. Magnetometry is the most common geophysical technique for geological mapping, mineral and oil exploration.

Access to this information treasure is oriented by the proper processing of raw satellite and processing data. Airborne geophysical data are collected at the regional scale and are often utilized for identifying the lateral lithological changes and areas with high mineralization potential. Appropriate points for drilling can be suggested by using and interpreting geophysical data along with geological, mineralization, alteration, and geochemical information. Next, the depth, shape, and size of the deposit can be evaluated and estimated by integrating this information. Satellite data must be subjected to radiometric and geometric preprocessing before use. Log Residuals method has been used for radiometric correction to eliminate sunlight, atmospheric scattering, topographic effects, and albedo effects based on the amount of reflection of satellite images (Feizi and Mansouri, 2012). This transfer produces a false reflection image that is useful for analyzing geological features and mineral applications. The software used in this study is ENVI 5.1 and the number of bands used in the ASTER images is 9. 


\section{GEOLOGY OF THE AREA}

Urmia-Dokhtar magmatic belt with a length of $1600 \mathrm{~km}$, extending from northwest to south of Iran, includes felsic to intermediate pyroclastic rocks with the age of Cretaceous to Eocene age that is penetrated with granitoid massifs with Eocene-Oligocene to Miocene age. This belt has been formed by the subduction of the Saudi Arabia plate under the Iranian subcontinent within the Late Jurassic to the Miocene (Mohajjel et al., 2003, Shafiei, 2010). Several geologists have considered this belt among the potential areas for porphyry copper mineralization regarding its tectonic setting.

Porphyry copper indices along with vein and skarn copper mineralization are among the most important types of copper deposits. Such deposits vary in terms of geological environment, type of the included rock, mineral geometry, twins, formation, and grade (Navai, 2002, Yazdi et al., 2017). Regarding the tectonic environment, most porphyry copper deposits are formed through igneous activities caused by anodic subduction and the formation of type I granitoids. Since most of Iran's porphyry copper deposits are found along with tertiary volcanic and more plutonic rocks, most of the porphyry copper mineral indices identified are expected to be located in the Urmia-Dokhtar belt. The study area is located at $53^{\circ} 00^{\prime}$ to $53^{\circ} 30^{\prime} \mathrm{E}$ and $32^{\circ} 00^{\prime}$ to $32^{\circ} 30^{\prime} \mathrm{N}$ in the west of Yazd province. The rock units of the area can be divided into three categories. The first group includes Pre-Eocene volcanic and plutonic rocks with severe folding and faulting in the northeast corner. The second group is comprised of tertiary volcanic sedimentary rocks with milder folding in the western part. Finally, the third group is comprised of ophiolite complexes as a narrow strip extending from the northwest to the southeast of the area (Amidi and Nabavi, 1980, Yazdi et al., 2019 a-b). The most important volcanic rock unit in the region is Aplite granite, granite, granodiorite, and diorite, which are mostly found in the south of the plate (Amidi and Nabavi, 1980, Bazoobandi et al.2016, Baratian et al., 2018). The volcanic rock units include rhyodacite in the southeast, andesitic and trachyandesitic basalts in the center to the west of the plate (Amidi and Nabavi, 1980). There are several abandoned lead and zinc mines in the northwest of Haftar (Amidi and Nabavi, 1980). The most important orebody in the Sarve Bala sheet is the Surak iron ore mine, formed associated with the main Dehshir-Baft fault, around which several alterations are observed (Zare, 1995) (Figs. 1 and 2). The Dehshir fault with the general direction of NNW-SSE has partially crossed the structural zones of Sanandaj-Sirjan, Urmia Dokhtar, and Central Iran magmatic arc. It is considered the western boundary of the set of the north-south dextral strike-slip fault of central Iran and eastern Iran, which is very important in terms of color mix expansion (Nazemi et al., 2019, Shafaii et al., 2010).

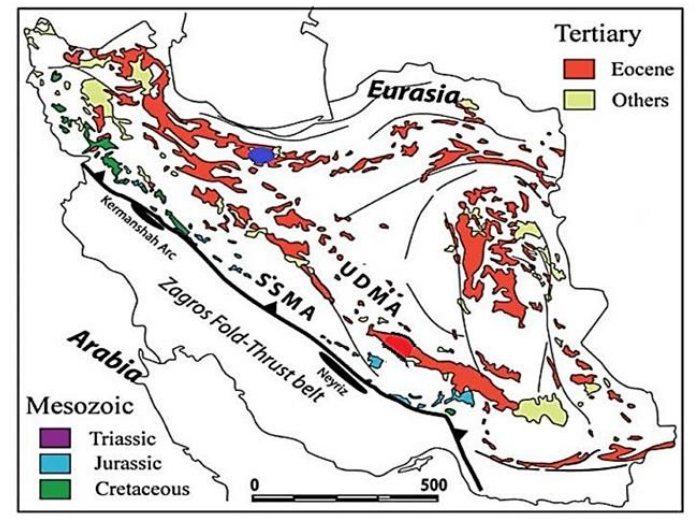

Figure 1. The study area in the structural zones map of Iran (Agard et al., 2011) 


\section{FIELD STUDIES AND MINERALOGICAL RESULTS}

Field visits and sampling were performed based on the geological maps and desk studies of Zereshk valley, Khezrabad, and Sarv Bala areas (Figs. 2a and 2b). Infiltration of Zereshk valley granitoid stock in the sedimentary units of Taft limestone formation has been associated with the processes of contact metamorphism, marbleization, and hornfels skarnoid formations. Accompanied by the crystallization of the plutonic mass, the leakage and outflow of metasomatic fluid from the plutonic mass have caused numerous small fractures in the host rock to occur the metasomatic alteration and skarn formation by entering the metallic fluids in the host rock. According to the field evidence and microscopic skarn studies, Zereshk Valley mainly includes two in-skarn and limited zones and out-skarn zones. Out-skarn is the main skarn and ore zone of Zereshj Valley. Pyroxene, garnet, epidote, actinolite, chlorite, calcite, quartz, clay minerals, and turbid minerals are the main constituents of this zone.

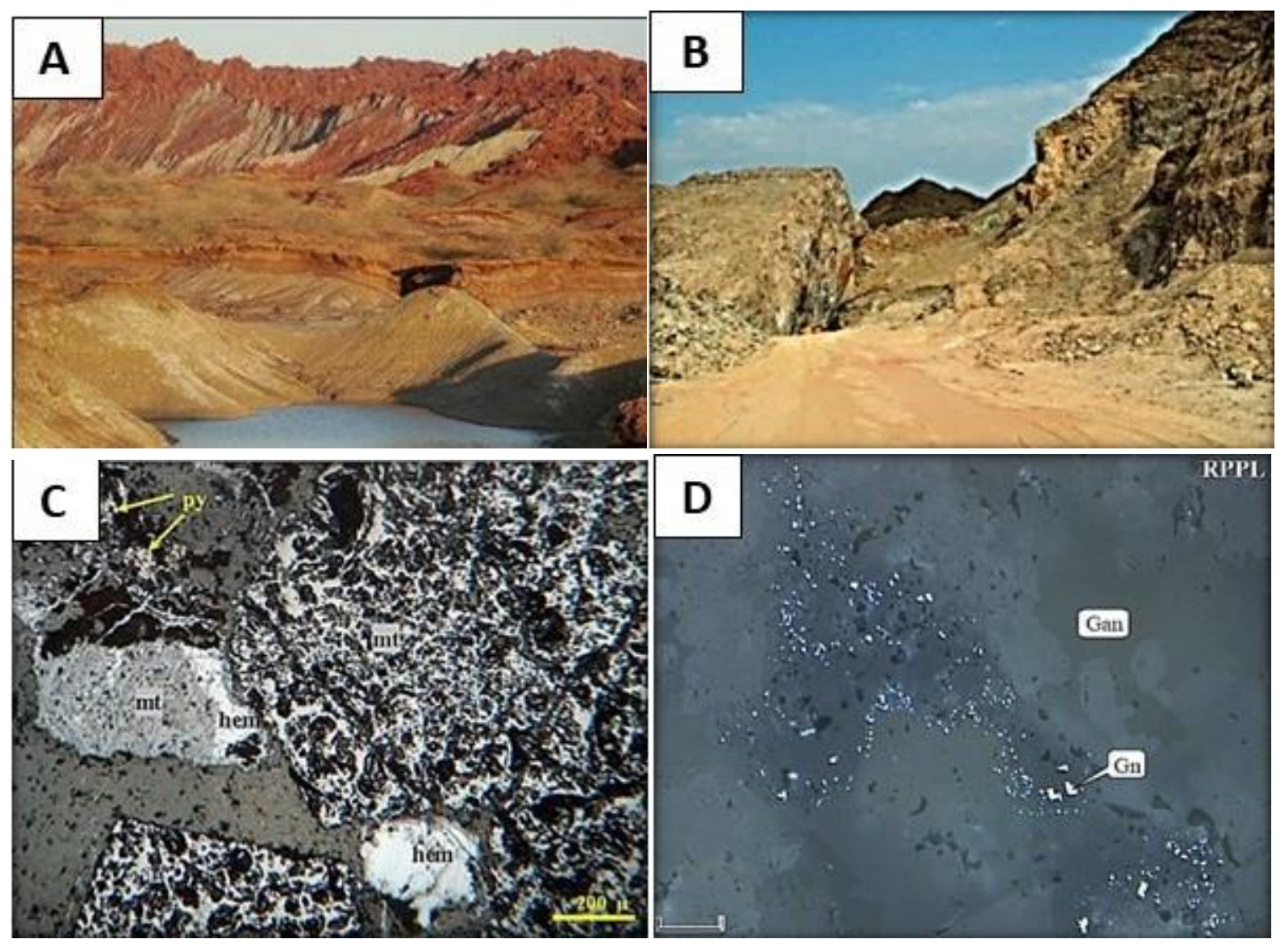

Figure 2. a) The view of the Zereshk Valley mine; b)View of Khezrabad mine; c) The presence of magnetite with hematite and pyrite; d) The fine gallons crystals

The geochemical properties of granitoids in Zereshk Valley are similar to many skarn, granite, copperiron, and copper-gold granitoids. This indicates the significance of Zereshk Valley skarns in terms of copper, iron, and gold potential. Zereshk Valley skarns have been formed in an oxidative environment 
during metasomatic alteration. This is demonstrated by relatively oxidized mineralogical skarns of Zereshk Valley (garnet andradite, pyroxene diopside, magnetite, and hematite) and chemical comparison of Zereshk Valley granitoid composition with other skarn granitoids. Furthermore, positive and high Eu anomalies in skarn zones, as well as in skarn-forming plutonic mass, are suggestive of this potential (Mar et al., 2011). The large plutonic mass of Khezrabad, which consists of alkali granite to granodiorite, is the only outcrop of plutonic mass in the region that has crossed the destructive sediments of Paleozoic and Cretaceous carbonates and caused the development of Hornfels skarn. Amidi (1989) has studied the circular plutonic masses (caldera-like) with a composition of diorite, quartz diorite, tonalite, granodiorite, and granite with the Oligocene age in the Sarve Bala area. These rocks have penetrated volcanic rocks (with a composition of rhyolite and rhyodacite) and pyroclastic rocks (andesitic tuff, rhyodacite, and rhyolite with the age of Eocene) (Amidi, 1989; Fazeli et al., 2016). This calc-alkaline type-I granitoid magma has a high oxygen fugacity, for which the formation environment has been considered as a subduction-related volcanic arc. The paragenetic mineralogy sequence of Zereshk Valley is represented in Fig. 3. The reserve volume of this mine was estimated as 23 million tons with a copper grade of 0.80 to 0.97 in 2004 (Zarasvandi et al., 2004).

\begin{tabular}{|c|c|c|c|c|c|c|}
\hline & \multirow{3}{*}{ Minerals } & \multirow{3}{*}{$\begin{array}{l}\text { Metamorphic } \\
\text { stage-non- } \\
\text { metasomatism } \\
\text { (I) }\end{array}$} & \multicolumn{3}{|c|}{ Metasomatism alteration and mineralization } & \multirow{3}{*}{$\begin{array}{l}\text { Outcropped } \\
\text { alterations }\end{array}$} \\
\hline & & & \multirow[b]{2}{*}{$\begin{array}{c}\text { Progressive } \\
\text { stage (II) }\end{array}$} & \multicolumn{2}{|c|}{ Regressive stage } & \\
\hline & & & & $\begin{array}{l}\text { Early } \\
\text { regressive } \\
\text { (III) }\end{array}$ & $\begin{array}{l}\text { Late } \\
\text { regressive } \\
\text { (IV) }\end{array}$ & \\
\hline \multirow{6}{*}{ 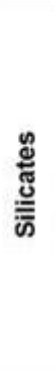 } & Garnet (Grandite) & & & & & \\
\hline & Diopside - Hedenbe & & & & & \\
\hline & Thermolite-actino & & & & & \\
\hline & Epidote & & & & & \\
\hline & Chlorite & & & & & \\
\hline & Quartz & & & & & \\
\hline \multirow{4}{*}{ 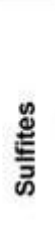 } & Chalcopyrite & & & & & \\
\hline & Bornite & & & $=$ & & \\
\hline & Chalcocite & & & & & \\
\hline & Digenite & & & & & \\
\hline \multirow{3}{*}{$\frac{n}{\frac{n}{x}}$} & magnetite & & & & & \\
\hline & hematite & & & & & \\
\hline & Goethite & & & & & \\
\hline \multirow{2}{*}{ 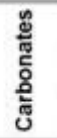 } & Calsite & & & & & \\
\hline & Malachite-Azurite & & & & & \\
\hline
\end{tabular}

Figure 3. The paragenetic sequence of Zereshk Valley mineral complex (Mar et al., 2011) 
Through the field studies, copper and iron indices were observed in some areas. A correlation was found between the outcrop of iron oxide alterations near the Dehshir-Baft fault in Surak and Surak iron orebody in the study area. Therefore, the relation between the iron mineralization and related alterations along the Dehshir fault zone can be confirmed. Sampling was performed through the field surveys. The results of XRD mineralogy studies are presented in Table 1.

Table 1. The results of XRD analysis

\begin{tabular}{|c|c|}
\hline$\underline{\text { S. NO }}$ & $\underline{\text { XRD RESULTS }}$ \\
\hline B7 & QUARTZ+ CALCITE \\
\hline B18 & Cryptomelane+ Calcite+ QUARTZ \\
\hline A6 & QUARTZ+ Otrthoclase+Albite \\
\hline B4 & QUARTZ+ CALCITE \\
\hline A2 & CALCITE + + Otrthoclase +QUARTZ+Hematite+Kaolinite \\
\hline B11 & QUARTZ+ CALCITE \\
\hline
\end{tabular}

\section{REMOTE SENSING STUDIES}

The preparation of mineral potential maps is one of the most significant applications of GIS. This process can be divided into 4 stages:

Step 1. Establishing a model as an orebody model: To prepare a mineral potential map, the first step is to provide a model of the desired mineralization (i.e., the orebody model).

Step 2. Collecting spatial data and creating a database, which takes the highest time of GIS projects.

Step 3. Data processing: In this step, the collected data are processed and are integrated and modeled as indicator maps based on the exploratory model.

Step 4. Applying integration models: The final step includes combining different index maps. In a given project, different mineral potential maps may be obtained because of the method used, information layers selected, and the weighting. In general, the maps can be valued and weighted in two ways:

(1) Analysis of the importance of the marker maps relative to the known orebodies and mineral indices in the region

(2) Expert's judgment

After drawing geochemical data polygons (grade) in the ArcGIS software, the average grade value of each polygon was obtained. The polygons for the geophysical data of the aerial magnetometer were also drawn and scored based on the maximum and minimum values. The data were integrated with buffers of major and minor faults and other geological data including mineralization and active and abandoned mines in the area. This important point was separately evaluated for each element in the corresponding 1:100,000 sheet. Considering the sensitivity and quantitative quality of gold, the available data were integrated into 
ArcGIS software using the "combined formula with standard weighting" to obtain a mineral potential map in addition to the integrated formula without weighting factor (Figs. 4a to 4d).
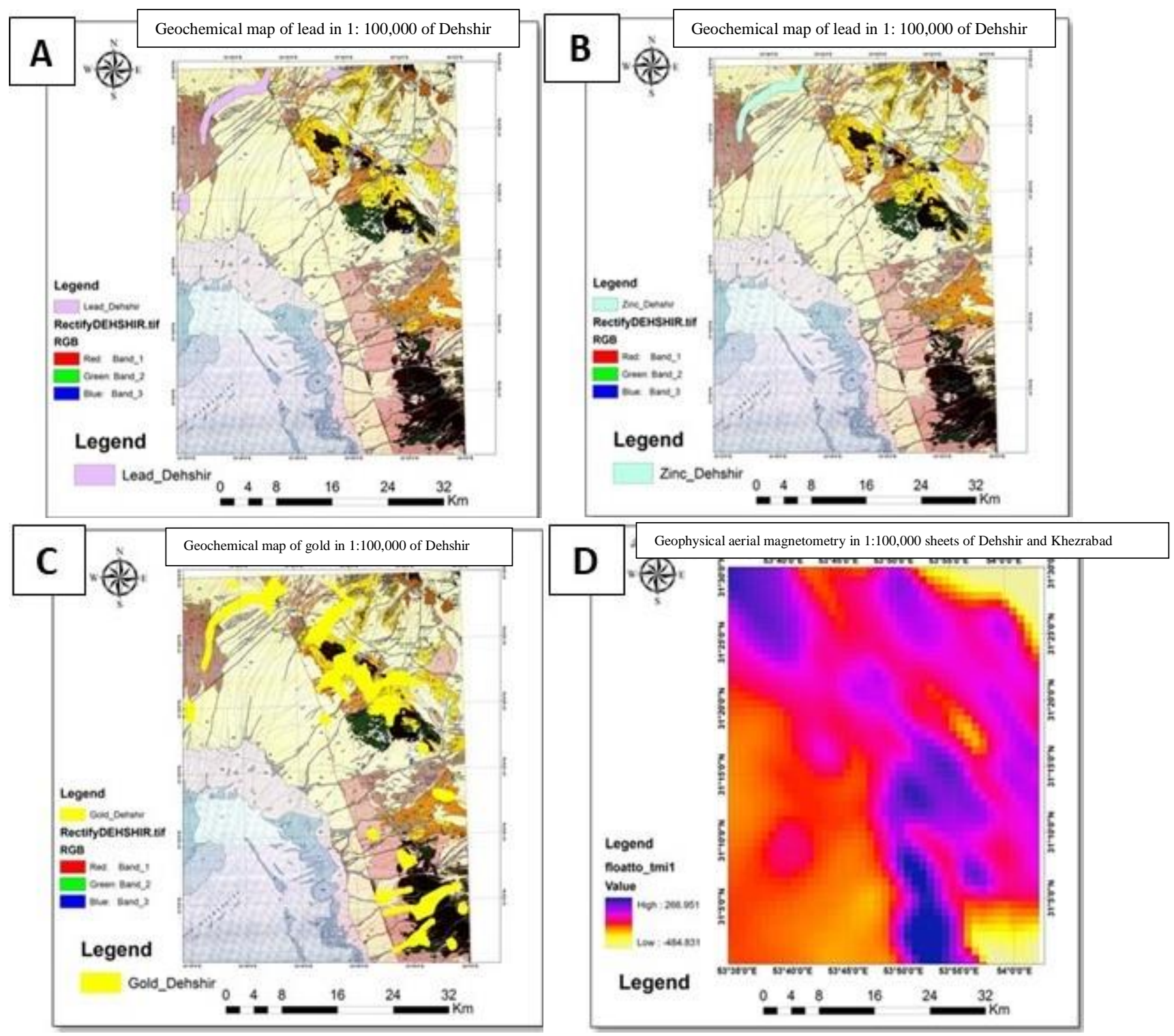

Figure 4. a) The polygon drawn from lead grade (ppm) data in 1:100,000 map of Dehshir; b) The polygon drawn from zinc grade data (ppm) in 1:100,000 map of Dehshir; c) The polygon drawn from gold grade data (ppb) in 1:100,000 map of Dehshir; d) The geophysical map of aerial magnetometry of 1:100,000 map of Dehshir and the southern side map of Khezrabad

The data of the maps were integrated using the following formula:

(Lead geochemical data + mineralization in the region+ lead lithology data + fault data) $/ 4$

(Zinc geochemical data + mineralization in the region+ zinc lithology data + fault data) $/ 4$

(Gold geochemical data + mineralization in the region+ gold lithology data + fault data)/4 
According to Fig. 5, the highest concentration of magnetometric value is around the Dehshir-Baft fault. The eastern part of the map, marked with an arrow in the figure, can be used to search for elements such as iron and copper. The presence of almost two areas with a higher concentration of magnetometer value at the top of the 1:100,000 Dehshir map and the southwestern side map of 1:100,000 Khezrabad sheet reveals the possible existence of plutonic intrusions masses considering the mild topography of these areas.

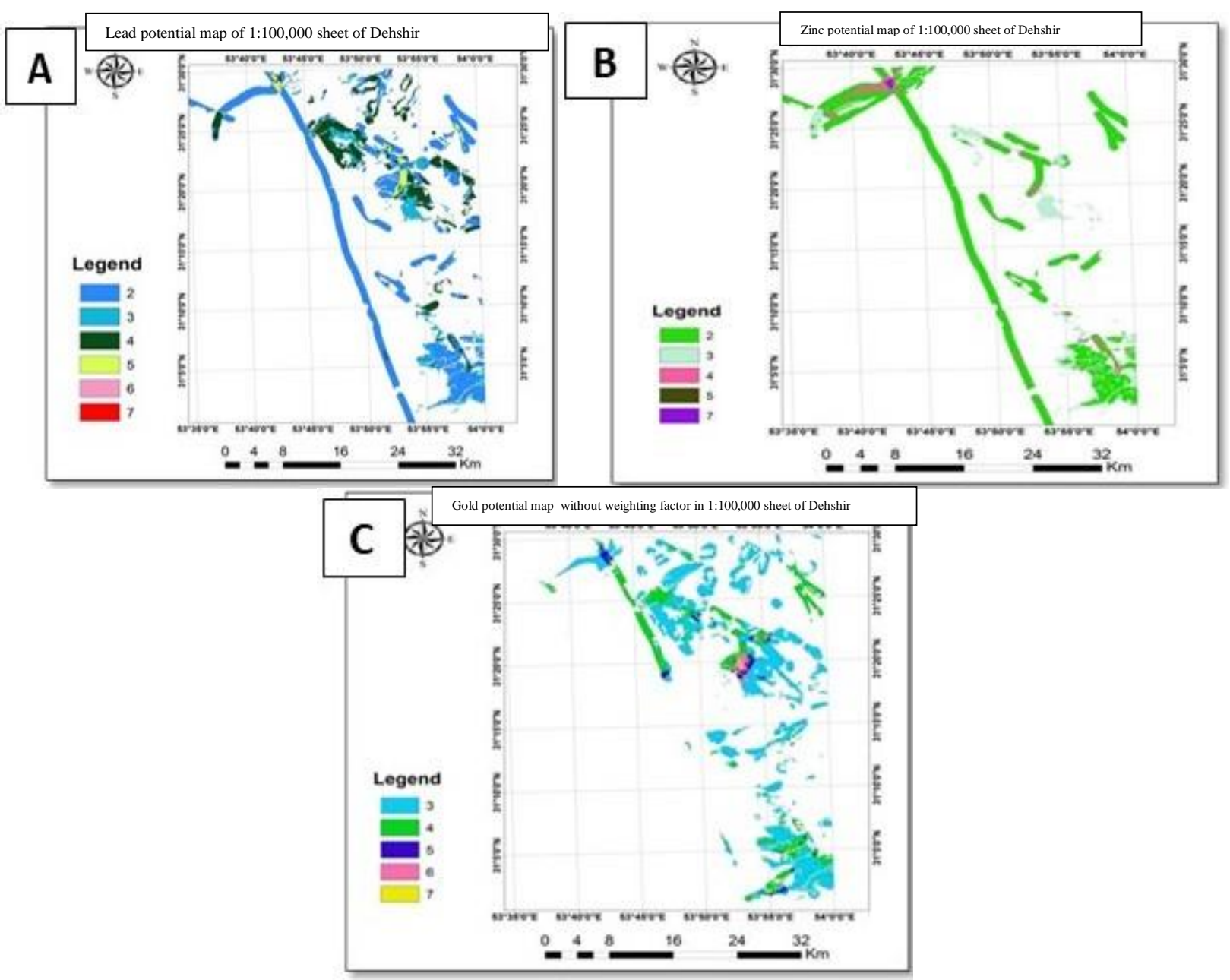

Figure 5. a) The potential map of lead in 1:100,000 Dehshir sheet; b) Zinc potential map in 1:100,000 Dehshir sheet;

c) Gold potential map without applying weight coefficient in 1:100,000 Dehshir sheet

\section{INTEGRATING INFORMATION LAYERS OF ALTERATIONS AND FAULTS}

All the alteration layers extracted by different methods were inserted and integrated using the ArcGIS software. The alterations corresponding to the geological units were selected as the information layer of the alterations. The highest score was assigned to the units associated with mineralization rocks, which were integrated with the fault map. Surak iron orebody in the southeast of the study area was used as a useful information layer for integration (Fig.7). In the classification for integrating the data, the number of rankings for promising areas was considered as 5 units and the promising areas were separated by colors. 
Fig. 7 represents a good consistency between the information layers in the southeast and northeast of the Sarve Bala sheet.

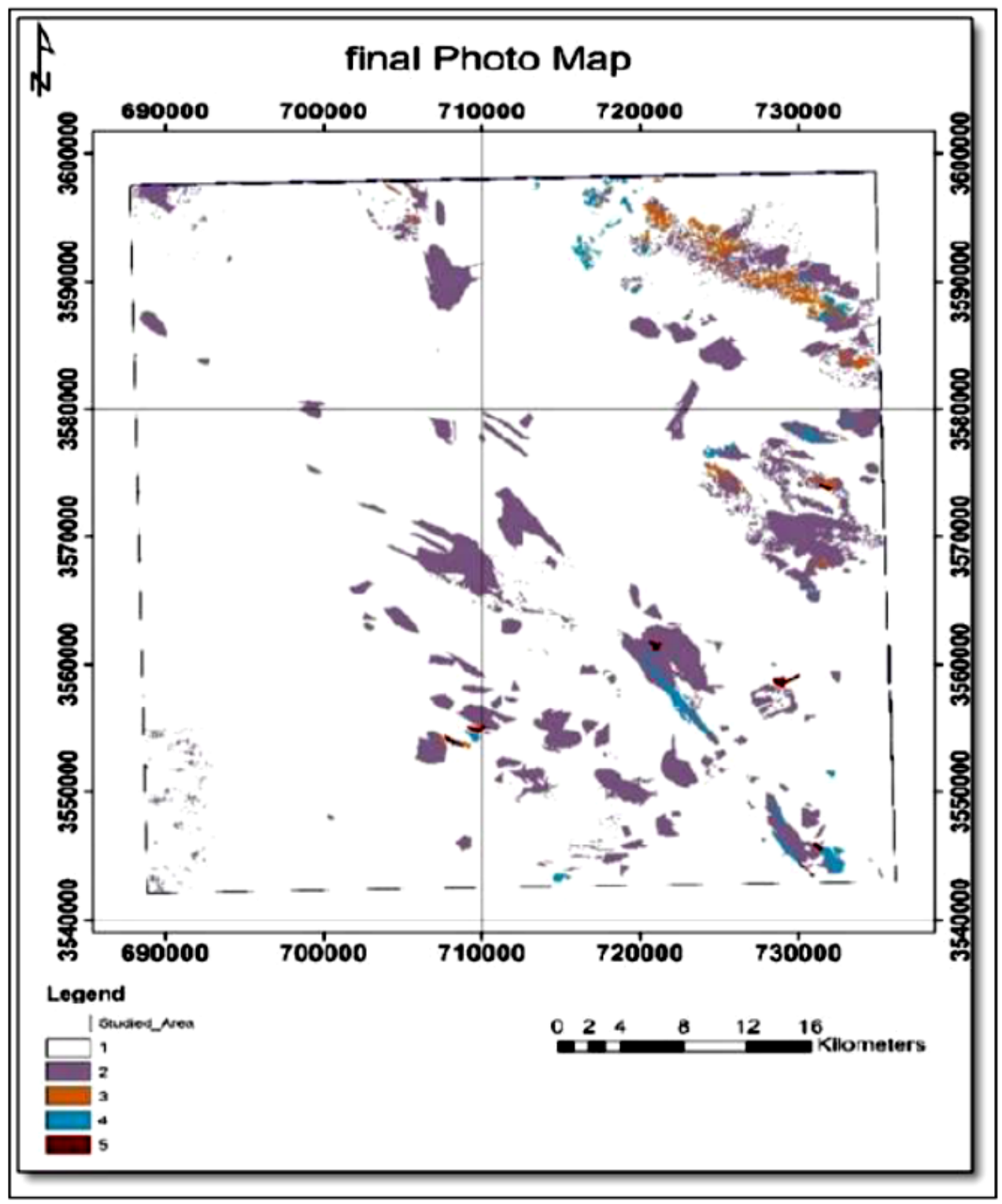

Figure 6. The final map of alterations and faults in Sarve Bala geological sheet (Source: Based on ASTER data of YAZD STEEL COMPANY, 2013) 


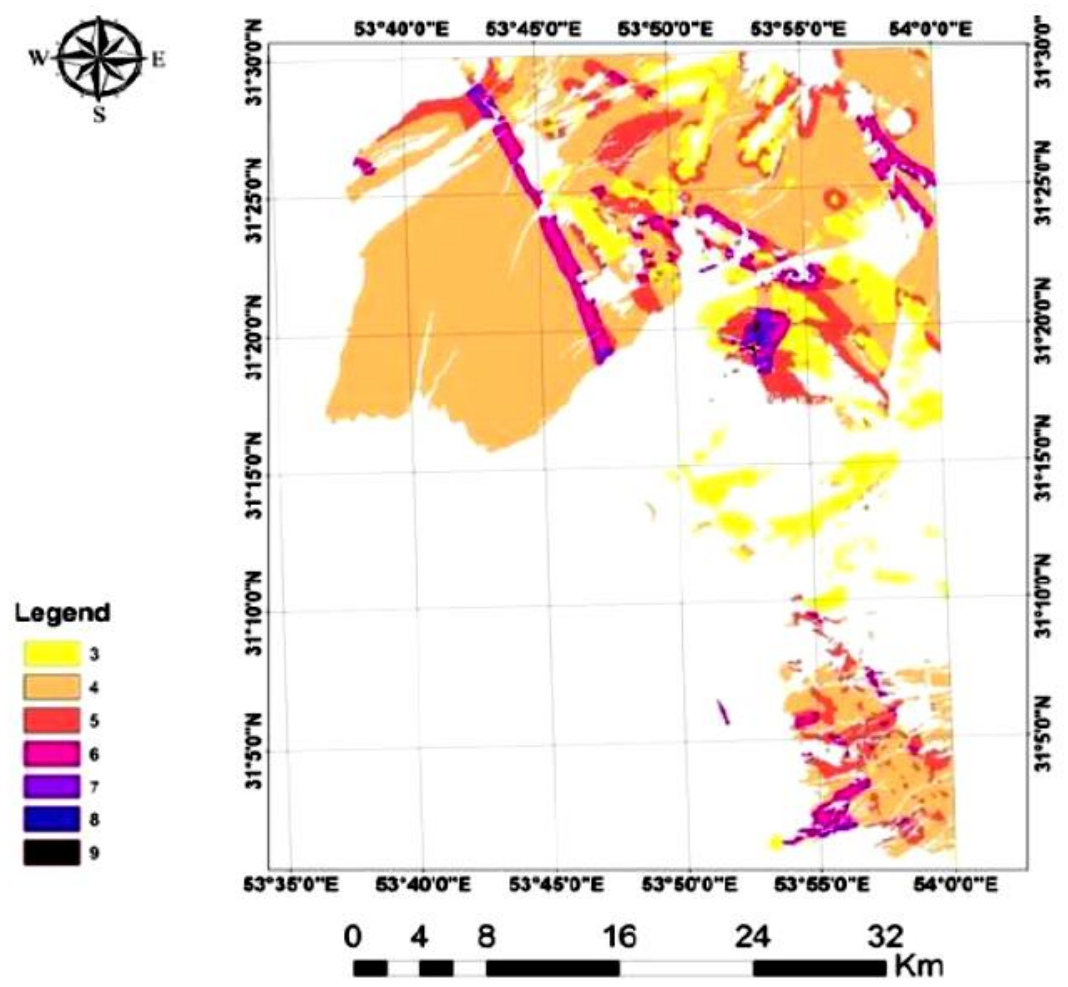

Figure 7. The priority of mineralization exploration in Dehshir sheet (Source: Based on ASTER data of YAZD STEEL COMPANY, 2013).

\section{CONCLUSION}

In the present research, the geochemical, geological, and remote sensing maps, as well as geological maps of Dehshir and Sarvbala areas, were integrated using fuzzy operators. The higher fuzzy values in the northern and eastern parts of the mentioned maps indicate a significant overlap of the anomalies in this area. The direct mineralization relationship between the elements of lead and zinc, as well as the great overlap of these two elements in the integrated maps obtained from ArcGIS software, facilitated finding the potential of these two important and economic elements in the 1:100,000 Dehshir sheet. There are two types of mineralization in the 1:100,000 Dehshir sheet. According to the available evidence, the source rock is Listwanite, which has been released under gold erosion. Thus, to examine the gold grade, it is necessary to drill exploratory wells in the study area based on the integrated gold maps.

Considering all three elements in the form of massive sulfide deposits (based on the geological and lithological situation of the area), the values obtained in the geochemical data within the aureole limit can be used to trace halos from the Kuroko deposit. The possibility of Kuroko and sometimes Cypriot mineralization can be attributed to the presence of Flysch-type sediments, dunites, Pillow Lava, Harzburgite, and Lherzolite.

\section{REFERENCES}

Agard, P., Omrani, J., Jolivet, L., Mouthereau, F. (2011) Convergence history across Zagros (Iran): Constraints from collisional and earlier deformation, International Journal of Earth Sciences, 
94(3):401-419

Amidi, M., Nabavi, M. (1980) Geological map of Sarve Bala 1: 100,000, Geological Survey and Mineral Exploration, Tehran.

Amidi, M., Nabavi, M. H. (1989) Geological Map of Sarve bala. Tehran, Geological Survey of Iran, scale 1:100,000.

Baratian, M., Arian, MA., Yazdi, A. (2018) Petrology and petrogenesis of the SiahKuh intrusive Massive in the South of KhoshYeilagh, Amazonia Investiga, 7 (17), 616-629

Bazoobandi, MH., Arian, MA., Emami, MH., Tajbakhsh, G., Yazdi, A. (2016) Petrology and Geochemistry of Dikes in the North of Saveh in Iran, Open journal of marine science, 6 (02), 210-222

Fazeli, B., Khalili, M., ROY, B.R., Mansouri Esfahani, M., Loghmani Dastjerdi, Z. (2016) Petrology of Oligocene granitoids of Yaghmash Castle in the west of Yazd province. Economic Geology, No. 2, pp. 473-491.

Feizi, F., Mansouri, E. (2012) Identification of Alteration Zones with Using ASTER Data in A Part of Qom Province, Central Iran, Journal of Basic and Applied Scientific Research, 2 (10) 10173-10184.

Mohajjel, M., Fergusson, C.L., and Sahandi, M.R. (2003) Cretaceous-Tertiary convergence and continental collision, Sanandaj-Sirjan zone, western Iran: Journal of Asian Earth Sciences, v. 21, p. 397-412, doi: 10.1016/S13679120(02)00035-4

MR, F., Dimer, S., Taghipour, B.( 2011) The reproductive relationship between Skarni mineralization and petrogenesis of granitoid mass of Zereshk Valley (southwest of Yazd province). Journal of Economic Geology. No. 2:97-110.

Navai, A. (2002) A view on Iran's copper reserves: Origin and Distribution, Geological Survey of Iran, Internal Report, $234 \mathrm{p}$.

Nazemi, E., Arian, MA., Jafarian, A., Pourkermani, M., Yazdi, A. (2019) Studying The Genesis Of Igneous Rocks In Zarin-Kamar Region (Shahrood, Northeastern Iran) By Rare Earth Elements, Revista Gênero E Direito, 8 (4), 446466

Shafaii Moghadam, H., J.Stern, R., Rahgoshay, M. (2010) The Dehshir ophiolite (central Iran): Geochemical constraints on the origin and evolution of the Inner Zagros ophiolite belt.

Yazdi, A., Ashja Ardalan, A., Emami, MH ., Dabiri, R., Foudazi, M. (2019-a) Magmatic interactions as recorded in plagioclase phenocrysts of quaternary volcanics in SE Bam (SE Iran), Iranian Journal of Earth Sciences, 11 (3), 215225

Yazdi, A., Ashja-Ardalan, A., Emami, MH., Dabiri, R., Foudazi, M. (2017) Chemistry of Minerals and Geothermobarometry of Volcanic Rocks in the Region Located in Southeast of Bam, Kerman Province, Open Journal of Geology, 7 (11), 1644

Yazdi, A., Shahhosini, E., Dabiri, R., Abedzadeh, H. (2019-b) Magmatic differentiation evidences and source characteristics using mineral chemistry in the Torud intrusion (Northern Iran), Revista Geoaraguaia, 9 (2):1-21.

Zare, M., Heidari. M. (1995) A report on the preliminary seismicity of tectonics and the risk of seismic faults in Zanjan province. 